\title{
Firm Performance and Family Related Directors: Empirical Evidence from an Emerging Market
}

\author{
Hafezali lqbal Hussain ${ }^{1}$, Azlan Ali ${ }^{2}$, Hassanudin Mohd Thas Thaker ${ }^{3}$, Mohsin Ali $^{1}$
}

\begin{abstract}
Board composition is central to the worldwide corporate governance reforms that have taken place in recent years. The strong emphasis on director independence and board leadership is now part of all corporate governance regimes, including the regimes which has been introduced in Malaysia. It is the effectiveness of such provisions in the Malaysian business environment that provides the motivation for this paper. The literature shows mixed findings on the issues of board independence and board leadership. Our paper studies the role of directors with family connections and its impact on financial outcomes. We find that firms with a high presence of family related directors exhibit superior accounting profitability. However, such dominance is negatively viewed by the market (firm performance based on market measures), indicating that markets tend to perceive that domination of family members on the board could potentially lead to expropriation of wealth at the expense of other shareholders. Our results are supported by additional robustness tests. The findings provide interesting insights into the governance mechanisms of firms in an emerging market and its consequences for investor perceptions. Further implications are also discussed.
\end{abstract}

KEY WORDS: $\quad$ Firm performance, family related directors, corporate governance, board structure, board composition

JEL Classification: G32, G34

${ }^{1}$ Taylor's Business School, Taylor's University, Malaysia; ${ }^{2}$ University College of Technology Sarawak, Malaysia; ${ }^{3}$ Sunway University Business School, Sunway University, Malaysia

\section{Introduction}

The need for director independence and board leadership is an integral part of any corporate governance mechanism and has been emphasized in different regimes across the world, including the regimes of Malaysia. The motivation for this paper is derived from the measurement of the effectiveness of the implemen-

Correspondence concerning this article should be addressed to: Hafezali Iqbal Hussain, Taylor's Business School, Taylor's University, 1, Jalan Taylors, 47500 Subang Jaya, Selangor, Malaysia. E-mail: hafezali.iqbalhussain@taylors.edu.my tation of these governance regimes. Current findings in the literature further motivate our study, given that Abdullah (2004), Haniffa and Hudaib (2006) and Yatim, Kent, and Clarkson (2006) have failed to find any strong evidence to support the view that board independence and board leadership separation are efficient monitoring mechanisms that improve performance. These results have important policy implications, because the internal governance structures found in Malaysia at present are the result of firms adopting best practice as set down in the Malaysian Code of Corporate Governance (MCCG). This suggests that although 
firms are complying satisfactorily with the MCCG by adopting the prescribed structures, there does not appear to be the kind of positive impact on performance that was expected to result from the reforms now in place (Abdullah, Evans, Fraser, \& Tsalavoutas, 2015).

Interestingly, family related directors play an important role in corporate governance in the Malaysian context (Haniffa \& Cooke, 2002; Ismail \& Manaf, 2016). At the same time, the findings in the US demonstrate that trade-offs between different types of monitoring mechanisms are another important consideration (Agrawal \& Knoeber, 2001; Booth, Cornett, \& Tehranian, 2002; Mullins \& Schoar, 2016). In light the above findings, this paper explores the possibility that family related directors provide an alternative internal monitoring mechanism in the case of Malaysian firms, one that accounts for the missing link between governance and performance.

As suggested above, Malaysia provides a unique opportunity to study the implications of family linkages in corporate governance. This is because Malaysia is characterized by a relationship-based economic system (Abdullah \& Ismail, 2016; Rajan \& Zingales, 1998), where such arrangements are readily observable. Furthermore, the literature documents the importance of market and financial development in countries such as Malaysia in ensuring the maturity of the market (Chan \& Abd Karim, 2016). Although the study of the association between board characteristics and firm performance has already received considerable attention elsewhere, much of the empirical analysis of governance has been based on the open market economic systems that underlie the US and European experiences. Haniffa and Hudaib (2006), in their paper on Malaysian governance, argue that the effect of other countries' governance models is unlikely to be similar when applied in a different environment. This paper thus attempts to address this issue. Specifically, this paper considers whether family related directors add to firm performance

The implications based on the evidence provided in this study regarding the importance of family influence within a board structure would enable policy makers and the investment community to gain a better insight into the extent of the participation of these types of directors in Malaysian corporations. In terms of the involvement of family members in firm gover- nance, this study builds on studies by Lane, Astrachan, Keyt, and McMillan (2006), Lin and $\mathrm{Hu}$ (2007) and Miller, Breton-Miller, Lester and Cannella (2007) by introducing a more refined definition of CEO duality. Prior studies have usually defined CEO duality as the situation where the roles of CEO and Chairman are combined, while nonduality implies that different individuals serve as CEO and Chairman (Abdullah, 2004; Baliga, Moyer, \& Rao, 1996; Chi, Hung, Cheng, \& Lieu, 2015; Kang \& Zardkoohi, 2005). This study proposes that even when the positions of CEO and board chair are held by different individuals, it is possible nevertheless that these individuals are family related, in which case board leadership may also be considered as one of 'duality'. This new definition is motivated by the findings of Claessens, Djankov, \& Lang, 2000) in their work on the separation of ownership and control in listed corporations in a number of countries. The authors report that 85 percentof the sampled Malaysian corporations had managers who belong to a member of the controlling family or a nominee, and this evidence now suggests that duality may be more form than substance and should be reinterpreted within the relationship framework adopted here (Villalonga, Trujillo, Guzmán, \& Cáceres, 2018).The purpose of the study is to determine whether the insertion of family related directors has any impact on firm performance. We find that the appointment of family related directors, i.e., firms with a high presence of these directors, exhibit superior accounting profitability (as measured by ROA). However, the dominance of family related directors is negatively viewed by the market, suggesting that the market perceives that the domination of family members on the board could lead to potential agency issues at the expense of other shareholders.

In the next section we discuss the relevant literature as a motivation to our study, followed by a description of the sample, a definition of variables and the empirical model. Next, we discuss the findings from our analysis. Lastly, we conclude the paper with a discussion of the implications and limitations of our study.

\section{Literature Review}

\subsection{Measures of Firm Performance}

To date, several different approaches have been adopted in investigating the link between firm perfor- 

the firm (Acero \& Alcalde, 2016; González, Guzmán, Pombo, \& Trujillo, 2015). In this study, the term 'family related directors' (FRD) refers to directors who have an immediate family relationship with the firm's owners and officers. This is similar to the classification utilized in the literature (Yoong, Alfan, \& Devi, 2015). Following the above studies, ours will also categorize FRD as insiders, even though some studies have placed these directors under the category of affiliated (gray) directors (Wu \& Hsu, 2018).

However, the above evidence contradicts the evidence of family firms in East Asia. Claessens, Djankov, Fan, and Lang (1999) report that family control in East Asia leads to severe conflict with other residual claimants and impedes firm performance. Chen et al. (2005), in their study of family firms and firm performance (proxies by Return on Assets, Return on Equity and Market-to-Book ratio) in Hong Kong, fail to find any significant results. The problems faced by East Asian firms result from the prevalence of cross-holdings, pyramidal structure and dual class shares (Chi et al., 2015; Hashim \& Amrah, 2016). It has also been suggested that family firms engage in low transparent deals which relate to connection-based transactions (Mulyani Singh, \& Mishra, 2016). This may suggest that the impact of family-owned firms on governance and performance in these countries may not be as significant as in the US.

\subsection{The Malaysian Context}

The main publication dealing with the reform process in Malaysia is the Malaysian Code of Corporate Governance (MCCG). Ow-Yong and Guan (2000), in their comparison of standards between Malaysia and the UK, find that the Malaysian codes are regulatorydriven, whereas UK codes are voluntary and largely business-driven. The MCCG emphasizes the transparent and timely flow of information, the procedures for appointments and the role and powers of the board, along with executive directors' remuneration, financial reporting, internal controls and the relationship between the shareholders and the board. The MCCG represents the main private initiative taken to enhance corporate governance in publicly held firms. It seeks to create an enabling environment for the growth of private enterprises and for attracting foreign investment. In response to the changes in the business en- vironment and to improve its effectiveness, the MCCG was further revised in 2007, with key amendments of the code aimed at strengthening boards of directors and audit committees. Among the amendments in the revised MCCG 2007 are that executive directors will no longer be allowed to become members of the audit committee and that there will be greater clarity in the aspects which the nominating committee should consider when recommending candidates for directorships. The code was further revised in 2012 with a focus on corporate dealings and culture. Furthermore, firms were required to have a disclosure policy as well as a commitment to shareholders' rights.

As mentioned earlier, the Malaysian corporate governance model and commercial law are largely influenced by the UK experience. Hence, it is likely that many similarities can be found in board characteristics and in the general corporate landscape between Malaysia and the UK. For instance, the board model is similar in both Malaysia and the UK - a single tier or unitary board (Shim, 2006). The general view of Malaysian corporate ownership is largely that of control by a small group of related parties or by owner-managers. The ownership structure is usually highly concentrated among a few individuals or their families, with some state involvement (AlQadasi \& Abidin, 2018)

In terms of board size, the published findings in the Malaysian context are similar to the US experience. On average, Malaysian firms have seven members on the board of directors (Wan Mohammad, Wasiuzzaman, \& Nik Salleh, 2016). In addition, the literature documents that Malaysian firms have a high concentration of ownership compared to those in the UK and the US (Hooy, Hooy, \& Chee, 2019). Their finding indicates that the ownership structure of companies in Malaysia is less diffuse and is dominated by companies with substantial shareholders, and these are typically families. Similar to evidence from earlier international studies, the relationship between ownership structure and firm performance in Malaysia also produces mixed results. Studies have also shown find that ownership concentration in Malaysian firms is negatively related to firm performance as measured by Tobin's Q and return on assets (Alias, Yaacob, \& Jaffar, 2017; Wang \& Shailer, 2015). In contrast, the literature is also contentious where studies document a positive correlation between block holder ownership (five per- 

able on the Bursa Malaysia website, and the financial data are available from the Worldscope database. Data are obtained for the years 2001 to 2018, where pre2001 data are excluded due to the introduction of the MCCG in 2000. In addition, we eliminate firms where the ROA and ROE observed are outliers (more than 100 percent and less than -100 percent. After the data refinement process, the sample comprises 605 firms operating in 10 different industries and 10,128 firmyear observations.

For the ease of computation of firm performance indicators, previous empirical work on the Malaysian governance system, e.g., by Haniffa and Hudaib (2006), Abdullah et al. (2015) and Jong and Ho (2018), has excluded the data for firms with recorded negative equity book value and negative earnings. However, this study includes those firms with negative net worth and earnings as the primary interest is the relationship between the structure of the board and financial performance, and there is specific interest in the effects of family related directors, rather than the precise financial structure of the firm. The estimation using unbalanced panel methods is designed to enrich the evidence of internal governance mechanisms in Malaysian firms. The advantages of applying panel data methods as suggested by Hsiao (2014) include (a) controlling for individual heterogeneity, (b) modeling the dynamics of adjustment in the variables, and (c) measuring effects that are simply not detectable with pure cross-section and pure time-series data.

\subsection{Variables}

For this study, 11 variables are selected for use in the investigation, and these variables are from two categories, i.e., board characteristics and financial variables. For board characteristics and control variables, the variables are family related directors (FRD), the percentage of independent directors, board leadership structure, board size and board meeting frequency. Other control variables include firm size, the percentage of ownership stake held by the top five shareholders and leverage as control variables. Financial variables are based on return on assets, market-to-book ratio and the modified Tobin's Q.

Board characteristics are manually accessed from the company's annual report and the corporate database available at the Bursa Malaysia website. The inclu- sion of the percentage of equity held by the top five largest shareholders is motivated by the work of Haniffa and Hudaib (2006) and Dinh and Calabrò (2019). For firm performance indicators, we select three profitability and market valuation proxies, which are widely used in much governance literature, namely, Return on Assets (ROA), Market-to-Book Ratio (MTB) and the Modified Tobin's Q (MTQ). The definition of variables utilized in the model are provided in Table 1 below.

\subsection{Hypothesis and Model Specification}

Based on the arguments put forward by Fama and Jensen (1983) and DeAngelo and DeAngelo (1985), family-controlled firms are likely to be more effective at aligning interests between managers and shareholders. The risk of a managerial decision acting against the shareholders' interests is expected to be minimal in family-controlled firms, and this may result in more efficient operations and superior performance. Halim, Mustika, Sari, Anugerah, and Mohd-Sanusi (2017) further argue that firm performance can be measured via accounting ratios as well as market-based indicators.

Thus, our hypotheses are as follows:

Hypothesis 1: FRD is positively related to ROA

Hypothesis 2: FRD is positively associated with the MTB Hypothesis 3: FRD is positively related to MTQ

Our model is specified as follows for firm performance (FP), measured alternately by ROA, MTB and MTQ and is inclusive of time and industry dummies $[1,0]$ :

$$
\begin{aligned}
& F P_{i t}=\beta_{1} \operatorname{CONST}_{i t}+\beta_{2} F_{R D} D_{i t}+\beta_{3} I N D_{i t}+\beta_{4} \text { DUALITY }_{i t}+ \\
& +\beta_{5} \text { BSIZE }_{i t}+\beta_{5} \text { OWN }_{i t}+\beta_{7} \text { MEET }_{i t}+\beta_{8} \text { FSIZE }_{i t}+ \\
& +\beta_{9} L E V_{i t}+\varepsilon_{t+1}
\end{aligned}
$$

\section{Empirical Results and Discussion}

\subsection{Describing the sample and univariate analysis}

Table 2 below reports the descriptive statistics for all variables used in this study. The raw data for ROA displays a serious asymmetric distribution and outlier problems. To mitigate this, we trim all the variables. This has been achieved by setting a cut-off percentage of -100 and 100 for ROA, which thus allows statistical estimations that avoid the effect of extreme values 
Table 1. Definition of variables

\begin{tabular}{|c|c|c|}
\hline Variables & Label & Definition \\
\hline \multicolumn{3}{|l|}{ 1. Board and firm characteristics } \\
\hline Family related directors & $F R D$ & $\begin{array}{l}\text { Total number of directors who have a family relationship } \\
\text { with other directors on the board. }\end{array}$ \\
\hline Independent directors (percentage) & IND & $\begin{array}{l}\text { Percentage of independent nonexecutive directors on the } \\
\text { board. }\end{array}$ \\
\hline CEO/Chairman duality roles & DUALITY & $\begin{array}{l}\text { A dummy variable takes on the value } 1 \text { if the CEO is also } \\
\text { the Chairman of the board and/or if CEO and Chairman are } \\
\text { related in terms of a family relationship; otherwise it is } 0 \text {. }\end{array}$ \\
\hline Board size & $B S I Z E$ & Total number of directors on the board. \\
\hline Top 5 shareholders (percentegae) & OWN5 & $\begin{array}{l}\text { The proportion of shares owned by the five largest } \\
\text { shareholders to total shares outstanding in the company. }\end{array}$ \\
\hline Board meeting frequency & MEET & Number of board meetings held during the financial year. \\
\hline Firm size & FSIZE & Natural log of total assets measured in 2008 prices. \\
\hline Leverage & LEV & The ratio of total debt over total assets. \\
\hline
\end{tabular}

\section{Accounting profitability and market valuation}

\begin{tabular}{|c|c|c|}
\hline Return on assets & $R O A$ & $\begin{array}{l}\text { The ratio of earnings before interest and taxes to book } \\
\text { value of total assets. }\end{array}$ \\
\hline Market-to-Book ratio & MTB & $\begin{array}{l}\text { Market value of equity divided by total book value of } \\
\text { equity at year t. }\end{array}$ \\
\hline Modified Tobin's Q & MTQ & $\begin{array}{l}\text { Market value of equity plus book value of total debt } \\
\text { divided by book value of total assets. }\end{array}$ \\
\hline
\end{tabular}

Source: Adapted from "Corporate governance structure and performance of Malaysia listed companies" by Haniffa and Hudaib (2006) in Journal of Business Finance and Accounting, 33(7-8), 1040; "Asian family firms through corporate governance and institutions: a systematic review of the literature and agenda for future research" by Dinh and Calabrò (2019), International Journal of Management Reviews, 21(1), 56.

of ROA (Kothari, Laguerre, \& Leone, 2002). Furthermore, naive interpretation of statistics derived from data sets that include outliers may be misleading.

This study focuses on FRD where the median is two, as reported above. The maximum number for FRD throughout the analysis is eight. This preliminary analysis is consistent with earlier evidence described by Johnson and Mitton (2003) and Haniffa and Cooke (2002) of the extent of family related directors' involve- ment in public corporations in Malaysia. Both studies came to the conclusion that a significant number of family related members are evident on the boards of Malaysian companies. However, our interpretation is that while such directors can be numerous in some firms, as the maxima show, the key feature seems to be the expectation of two FRD, further demonstrating that linked directorships are usual in public corporations but not necessarily a dominant feature. It can be 
Table 2. Descriptive Statistics

\begin{tabular}{lccccccccccc}
\hline & FRD & IND & Duality & BSIZE & OWN5 & MEET & FSIZE & LEV & ROA & MTB & MTQ \\
\hline Mean & 1.52 & 48.45 & 0.35 & 7.62 & 47.10 & 5.37 & 19.66 & 0.23 & 0.03 & 1.78 & 0.85 \\
Median & 2.00 & 47.50 & - & 7.00 & 48.99 & 5.00 & 19.43 & 0.21 & 0.04 & 1.87 & 0.73 \\
Min & 0.00 & 0.20 & - & 3.00 & 0.00 & 0.00 & 15.35 & 0.00 & -0.63 & 0.91 & 0.06 \\
Max & 8.00 & 100.00 & - & 17.00 & 98.76 & 27.00 & 24.87 & 0.87 & 0.66 & 2.02 & 7.83 \\
StdDev & 1.74 & 10.80 & 0.48 & 1.95 & 20.86 & 2.21 & 1.33 & 0.18 & 0.09 & 0.26 & 0.55 \\
\hline
\end{tabular}

seen that the FRD data distribution shows an overall mean (1.52) that is relatively low by comparison with the standard deviation (1.74). There are two points to note here. First, as FRD is a count variable, the descriptive statistics are indicative only, as the lower bound is zero. Consequently, in the statistical analysis reported later in the paper, the variable is logged (Guest, 2009). A similar approach is adopted for BSIZE and MEET (Yermack, 1996). In addition, we employ a median regression model (Guest, 2009). Second, it should be emphasized that FRD is defined in this study by the existence of a family relationship among any of the board members. Therefore, FRD may be recorded as zero or as two or more but never as one. In this study, we classify a firm as having a joint leadership structure if it falls under one of two conditions. The first condition has been commonly used in many previous studies, i.e., when the CEO and Chairman roles are combined, and the second condition is when the CEO and Chairman of the board have a family relationship to one another. As far as we are aware, none of the previous studies on corporate governance structure have applied this approach. The definition used here is more appropriate, and justifiable, because the independence of leadership structure is questionable when the CEO and Chairman are related. In addition, the correlation matrix is reported in Table 3 below.

Table 4 below presents a comparison between firms with FRD. We find that there is a difference in ROA between firms with and without FRD. The T-test reveals a significant difference at the 1percent significance level. The result suggests that the appointment of FRD is related to higher firm performance, which is also reported by Hashim and Devi (2008), who found that the representation of family members on boards is likely to enhance earnings quality, as these directors have greater expertise of the firm's operations and thus effectively monitor the firm's activities more closely.

Table 4 also shows that firms with FRD have lower market values as measured by MTQ and MTB. The results suggest firms with FRD are valued lower than their counterparts as a result of FRD's influence on the firm's risk-averse strategy. However, this in turn could prevent the firm from suffering severe economic losses during the crisis. At the same time, we know that FRD is also viewed as a strong factor in firm survival (Ibrahim \& Samad, 2011; Neckebrouck, Schulze, \& Zellweger, 2018).

\subsection{Modeling Profitability}

We report the results for regressing our model in Table 5 below for the first performance measure. To estimate the model, we employ the OLS methods, which include time and industry dummies as reported in the first column for firm profitability (ROA). White (1980) standard errors are reported in parentheses. Our regressions include time and industry dummies. Independent directors (IND) are negatively related to ROA, confirming the results of Zabri, Ahmad, and Wah (2016) and Germain, Galy, and Lee (2014). Our findings, however, are in contrast with Fooladi, AbdulShukor, Saleh, and Jaffar (2014), which could be because our definition of independent directors differs from their study. This result indicates that the presence of IND may not have the intended influence on the quality of directors' deliberations and decisions and 
Table 3. Pairwise correlation of variables used in panel data analysis

\begin{tabular}{|c|c|c|c|c|c|c|c|c|c|}
\hline & $F R D$ & IND & BSIZE & OWN5 & MEET & FSIZE & LEV & $R O A$ & MTB \\
\hline IND & $-.239^{* * *}$ & & & & & & & & \\
\hline BSIZE & $.201^{* * *}$ & $-.269^{* * *}$ & & & & & & & \\
\hline OWN5 & 0.031 & $-.147^{* * *}$ & $.163^{* * *}$ & & & & & & \\
\hline MEET & -.019 & .019 & .031 & $-.037^{*}$ & & & & & \\
\hline FSIZE & .002 & $-.073^{* * *}$ & $.100^{* * *}$ & $.036^{*}$ & $209^{* *}$ & & & & \\
\hline LEV & $.077^{* * *}$ & $-.049^{* *}$ & -0.025 & $-.058^{* * *}$ & 0.025 & $.153^{* * *}$ & & & \\
\hline$R O A$ & 0.029 & $-.056^{* * *}$ & $.068^{* * *}$ & $.105^{* * *}$ & -0.029 & $.175^{* * *}$ & $-321^{* * *}$ & & \\
\hline MTB & $.065^{* * *}$ & $-.095^{* * *}$ & $.037^{*}$ & 0.029 & 0.028 & $149^{* * *}$ & $-.534^{* * *}$ & $-.188^{* * *}$ & \\
\hline MTQ & $-.038^{*}$ & $.056^{* * *}$ & 0.002 & 0.014 & -0.019 & $-.177^{* *}$ & $-.074^{* * *}$ & $.182^{* * *}$ & $-.156^{* * *}$ \\
\hline
\end{tabular}

Note: ${ }^{* * *}$ Significant at the 0.01 level, ${ }^{* *}$ significant at the 0.05 level, ${ }^{*}$ significant at the 0.1 level

Table 4. Univariate comparison of firms with FRD and firms without FRD

\begin{tabular}{lccc}
\hline Mean & Firms with FRD & Firms without FRD & T-test \\
\hline ROA & .04 & .03 & $3.22^{* * *}$ \\
MTB & 1.75 & 1.79 & $2.18^{* *}$ \\
MTQ & .84 & .87 & $2.04^{* *}$ \\
\hline
\end{tabular}

Note: ${ }^{* * *}$ Significant at the 0.01 level, ${ }^{* *}$ significant at the 0.05 level, ${ }^{*}$ significant at the 0.1 level

provide strategic direction and improvement in performance. This may also suggest that these directors lack real independence in enforcing monitoring. Interestingly, we find that after accounting for the influence of family relationships, DUALITY is not a significant determinant of firm performance, thus defeating the purpose of this particular form of corporate governance mechanism to safeguard shareholders' interests. Meeting frequency is negatively associated with ROA. A possible explanation of this situation is that a firm may increase its meeting frequency as a result of lower efficiency in assets investment. Ownership concentration is positively associated with ROA. This outcome is not consistent with findings by Tam and Tan (2007) and Ahmed Haji and Mubaraq (2015), who found a negative association between these variables. Our results differ because the measure of the ownership concentration used by both studies was computed solely for the ultimate owner of a firm. Nevertheless, our result reveals that the concentration of ownership control is linked to an efficient use of firm assets. Firm size has a positive coefficient while leverage has a negative coefficient.

The results for the key explanatory variable, i.e., for firm related directors (FRD), is statistically significant. The log coefficient of 0.0038 implies that if a firm with 2 family related directors were to increase by 2 (100 percent increase), the profitability of the firm would increase by approximately 0.004 . Thus, the existence of family related directors has a positive impact on firm 
Table 5. The impact of family related directors on return on assets (ROA).

\begin{tabular}{|c|c|c|c|c|}
\hline Variables & 1 & 2 & 3 & 4 \\
\hline \multirow[t]{2}{*}{ Intercept } & $0.0084^{* * *}$ & 0.0009 & $-0.1922^{* * *}$ & $-0.3345^{* * *}$ \\
\hline & $(0.0021)$ & $(0.0405)$ & $(0.0275)$ & $(0.1288)$ \\
\hline \multirow[t]{2}{*}{$F R D$} & $0.0038^{* * *}$ & $0.0044^{* * *}$ & $0.0031^{* * *}$ & $0.0035^{* * *}$ \\
\hline & $(0.0006)$ & $(0.0011)$ & $(0.0010)$ & $(0.0009)$ \\
\hline \multirow[t]{2}{*}{ IND } & $-0.0015^{* * *}$ & -0.0008 & $-0.0003^{* * *}$ & -0.0001 \\
\hline & $(0.0005)$ & $(0.0003)$ & $(0.0001)$ & $(0.0001)$ \\
\hline \multirow[t]{2}{*}{ DUALITY } & 0.0141 & 0.0089 & -0.0007 & 0.0005 \\
\hline & (0.1099) & $(0.0818)$ & $(0.0389)$ & $(0.0012)$ \\
\hline \multirow[t]{2}{*}{ BSIZE } & -0.0025 & -0.0019 & -0.0013 & -0.0008 \\
\hline & $(0.0269)$ & $(0.0385)$ & $(0.0012)$ & $(0.0682)$ \\
\hline \multirow[t]{2}{*}{ MEET } & $-0.0028^{* * *}$ & $-0.0036^{* * *}$ & $-0.0020^{* * *}$ & $-0.0023^{* * *}$ \\
\hline & (0.0009) & $(0.0008)$ & $(0.0007)$ & $(0.0008)$ \\
\hline \multirow[t]{2}{*}{ OWN5' } & $0.0010^{* * *}$ & $0.0006^{* *}$ & $0.0003^{* * *}$ & $0.0008^{* *}$ \\
\hline & $(0.0004)$ & $(0.0003)$ & $(0.0001)$ & $(0.0004)$ \\
\hline \multirow[t]{2}{*}{ FSIZE } & $0.0245^{* * *}$ & $0.0231^{* * *}$ & $0.0181^{* * *}$ & 0.0088 \\
\hline & $(0.0108)$ & (0.0099) & (0.0019) & $(0.0191)$ \\
\hline \multirow[t]{2}{*}{ LEV } & $-0.3114^{* * *}$ & $-0.2645^{* * *}$ & $-0.1671^{* *}$ & $-0.1232^{* * *}$ \\
\hline & $(0.1258)$ & (0.1028) & $(0.0846)$ & $(0.0401)$ \\
\hline \multirow[t]{2}{*}{$R O A_{t-1}$} & - & - & - & $0.3899^{* * *}$ \\
\hline & - & - & - & $(0.1028)$ \\
\hline Adjusted $R^{2}$ & 0.1828 & 0.2406 & 0.1682 & 0.4844 \\
\hline Sargan ( $p$-value) & - & - & - & 0.1288 \\
\hline Serial correlation ( $p$-value) & - & - & - & 0.2890 \\
\hline
\end{tabular}

Note: ${ }^{* *}$ Significant at the 0.01 level, ${ }^{* *}$ significant at the 0.05 level, ${ }^{*}$ significant at the 0.1 level

performance in Malaysia, thus extending and justifying the findings of Amran and Ahmad (2016) and Sharif, Kyid, and Wei (2015). The effect is also economically significant, as it would lead to an increase of about RM 21 million, which contradicts the findings of Ibrahim and Samad (2011). However, the authors' measure of family related firms was based on the ownership struc- ture rather than control point of view. Our findings also provide a rationale for the lackluster compliance to the MCCG by Malaysian firms as evidenced by Ahmed Haji (2014), given that the literature documents a large number of family related firms in the market.

Our results were obtained based on the OLS methods, which suffer from endogeneity concerns given 

Table 6. The impact of family related directors on market measures (MTQ \& MTB)

\begin{tabular}{|c|c|c|}
\hline Variables & 1 & 2 \\
\hline \multirow{2}{*}{ Intercept } & $0.0245^{* * *}$ & $2.833^{* * *}$ \\
\hline & $(0.0081)$ & $(0.8469)$ \\
\hline \multirow[t]{2}{*}{ FRD } & $-0.0903^{* * *}$ & $-0.2185^{* * *}$ \\
\hline & $(0.0252)$ & $(0.0634)$ \\
\hline \multirow[t]{2}{*}{ IND } & $0.0124^{* *}$ & 0.0021 \\
\hline & $(0.0060)$ & $(0.0322)$ \\
\hline \multirow[t]{2}{*}{ DUALITY } & $0.0408^{* *}$ & $0.1192^{* * *}$ \\
\hline & $(0.0205)$ & $(0.0372)$ \\
\hline \multirow[t]{2}{*}{$B S I Z E$} & $0.0382^{* *}$ & 0.0245 \\
\hline & $(0.0190)$ & $(0.0535)$ \\
\hline MEET & $0.0508^{* * *}$ & $0.0311^{* * *}$ \\
\hline \multirow[t]{2}{*}{ OWN5' } & $0.0191^{* *}$ & $0.0399^{* * *}$ \\
\hline & $(0.0096)$ & (0.0108) \\
\hline \multirow[t]{2}{*}{ FSIZE } & $0.0363^{* * *}$ & $0.0892^{* * *}$ \\
\hline & $(0.0129)$ & $(0.0255)$ \\
\hline \multirow[t]{2}{*}{ LEV } & $0.8129 * * *$ & $0.2422^{* * *}$ \\
\hline & $(0.0415)$ & $(0.0375)$ \\
\hline Adjusted $R^{2}$ & 0.1828 & 0.2406 \\
\hline
\end{tabular}

Note: ${ }^{* * *}$ Significant at the 0.01 level, ${ }^{* *}$ significant at the 0.05 level, ${ }^{*}$ significant at the 0.1 level

The director's independence has a positive coefficient, suggesting that markets view this as a positive move, contrary to Liew, Alfan, and Devi (2017) and despite our earlier results indicating that director's independence has a negative impact on firm performance. However, these discrepancies could be because our study treats nonexecutive directors who are related as nonindependent directors in order to fulfill our objective of studying the effect of family related directors' impact on performance. Thus, our findings highlight that market expectations may not necessarily be reflected in superior firm profitability. Investors thus tend to place a heavy reliance on independent directors to safeguard their interests. We observe a similar effect for duality. In addition, we find that board size and frequency of meetings have a positive and significant relationship, which is in line with Ibrahim and Samad (2011).

\section{Conclusion}

This study was motivated by the conclusions of several earlier studies, as discussed above, regarding governance mechanisms, specifically board independence and board leadership in Malaysia. However, these studies fail to find a strong link between board independence and board leadership structure and their effect on firm performance. Meanwhile, previous evidence has also shown that the integration of directors with family relationships into the commercial world is commonplace. 
We question the possibility that the affiliation of directors with family influence could influence Malaysian firms' financial performance. In addition, the extent of the effect of these directors on firm performance has not been empirically studied elsewhere, especially within emerging developing countries. Our study thus aims to fill this gap, given that Malaysia provides a unique opportunity to observe these factors. This study also introduces a new approach to identifying board leadership structure. Unlike previous studies, this study considers the family affiliation between $\mathrm{CEO}$ and Chairman in determining the leadership structure. This method accurately reflects the duality and nonduality structure. Hence, our measurement of independence also differs from previous studies.

Our findings suggest that the high involvement of FRD is related to the high efficiency of management in using its assets to generate earnings (as measured by ROA). From this finding, we argue that family directors possess superior information about the firm's operations and have a longer investment horizon, leading to greater investment efficiency. Thus, the first hypothesis is supported. On the other hand, the results also indicate that firms are valued less as a result of an increase in family related director representation, suggesting that the market perceives that the domination of family members on the board could lead to the potential expropriation of wealth at the expense of other shareholders. Therefore, the second and third hypotheses are rejected.

In other words, investors may perceive that firms with dominant family directors are lacking in the protection of minority stakeholders' interest because uncontested power rests with family owners. The mechanisms deployed to abuse the rights of minority stakeholders are numerous and quite well-known, and they range from the internal consumption of profits to the transfer of assets at below-market prices ("tunneling"); they also include other well-known tricks, among them the manipulation of transfer prices within conglomerates, the internal consumption of profits and the transfer of assets at below-market prices. However, it may also be argued that investors perceive the investment growth in firms with dominant family directors as unattractive as a result of owners being overly cautious in protecting their business legacy, while at the same time these firms are averse to venturing on big projects that may be risky.

\section{References}

Abdullah, S. N., \& Ismail, K. N. I. K. (2016). Women directors, family ownership and earnings management in Malaysia. Asian Review of Accounting, 24(4), 525-550.

Abdullah, M., Evans, L., Fraser, I., \& Tsalavoutas, I. (2015). IFRS Mandatory disclosures in Malaysia: The influence of family control and the value (ir) relevance of compliance levels. Accounting Forum, 39(4), 328-348.

Abdullah, S. N. (2004). Board composition, CEO duality and performance among Malaysian listed companies. Corporate Governance: The international journal of business in society, 4(4), 47-61.

Acero, I., \& Alcalde, N. (2016). Controlling shareholders and the composition of the board: Special focus on family firms. Review of Managerial Science, 10(1), 61-83.

Agrawal, A., \& Knoeber, C. R. (2001). Do some outside directors play a political role? Journal of Law and Economics, 44(1), 179-198.

Ahmed Haji, A., \& Mubaraq, S. (2015). The implications of the revised code of corporate governance on firm performance: A longitudinal examination of Malaysian listed companies. Journal of Accounting in Emerging Economies, 5(3), 350-380.

Ahmed Haji, A. (2014). The relationship between corporate governance attributes and firm performance before and after the revised code: Some Malaysian evidence. International Journal of Commerce and Management, 24(2), 134-151.

Alias, N., Yaacob, M. H., \& Jaffar, N. (2017). Governance structure, corporate restructuring and performance. Polish Journal of Management Studies, 15(1), 7-14.

AlQadasi, A., \& Abidin, S. (2018). The effectiveness of internal corporate governance and audit quality: the role of ownership concentration-Malaysian evidence. Corporate Governance: The International Journal of Business in Society, 18(2), 233-253.

Amran, N. A., \& Ahmad, A. C. (2010). Family succession and firm performance among Malaysian companies. International Journal of Business and Social Science, 1(2), 193-203.

Andres, C. (2008). Large shareholders and firm performance - An empirical examination of foundingfamily ownership. Journal of Corporate Finance, 14(4), 431-445. 
Baliga, B. R., Moyer, R. C. \& Rao, R. S. (1996). CEO duality and firm performance: What's the fuss? Strategic Management Journal, 17(1), 41-43.

Booth, J. R., Cornett, M. M. \& Tehranian, H. (2002). Boards of directors, ownership and regulation. Journal of Banking and Finance, 26, 1973-1996.

Basco, R., \& Voordeckers, W. (2015). The relationship between the board of directors and firm performance in private family firms: A test of the demographic versus behavioral approach. Journal of Management \& Organization, 21(4), 411-435.

Bhatt, P. R., \& Bhatt, R. R. (2017). Corporate governance and firm performance in Malaysia. Corporate Governance: The International Journal of Business in Society, 17(5), 896-912.

Born, B., \& Breitung, J. (2016). Testing for serial correlation in fixed-effects panel data models. Econometric Reviews, 35(7), 1290-1316.

Burgstaller, J., \& Wagner, E. (2015). How do family ownership and founder management affect capital structure decisions and adjustment of SMEs? Evidence from a bank-based economy. The Journal of Risk Finance, 16(1), 73-101.

Bun, M. J., \& Windmeijer, F. (2010). The weak instrument problem of the system GMM estimator in dynamic panel data models. The Econometrics Journal, 13(1), 95-126.

Cai, J., Liu, Y., Qian, Y., \& Yu, M. (2015). Information asymmetry and corporate governance. Quarterly Journal of Finance, 5(3), 1-32.

Chan, S. G., \& Abd Karim, M. Z. (2016). Financial market regulation, country governance, and bank efficiency: Evidence from East Asian countries. Contemporary Economics, 10(1), 39-54.

Chen, Z., Cheung, Y. L., Stouraitis, A. \& Wong, A. W. S. (2005). Ownership concentration, firm performance and dividend policy in Hong Kong. PacificBasin Finance Journal, 13(4), 431-449.

Chi, C. W., Hung, K., Cheng, H. W., \& Lieu, P. T. (2015). Family firms and earnings management in Taiwan: Influence of corporate governance. International Review of Economics \& Finance, 36, 88-98.

Choong, C. K., Chan, S. G., \& Pek, C. K. (2016). The effect of board composition on the efficiency of public listed companies in Malaysia. Economics Bulletin, 36(3), 1354-1363.
Chu, E. Y., Lai, T. S., \& Song, S. I. (2016). Corporate Governance and Financial Constraints in Family Controlled Firms: Evidence from Malaysia. International Journal of Business and Society, 17(3), 429-446.

Claessens, S., \& Fan, J. P. H. (2002). Corporate governance in Asia: A survey. International Review of Finance, 3(2), 71-103.

Claessens, S., Djankov, S. \& Lang, L. H. P. (2000). The separation of ownership and control in East Asian corporations. Journal of Financial Economics, 58(1-2), 81-112.

Claessens, S., Djankov, S., Fan, J. P. H. \& Lang, L. H. P. (1999). Expropriation of minority shareholders: Evidence from East Asia (Working Paper No. 2088). Washington, DC: World Bank. Available at http://documents.worldbank.org/curated/ en/283121468771272365/Expropriation-of-minority-shareholders-evidence-from-East-Asia

Cotter, J. F., Shivdasani, A. \& Zenner, M. (1997). Do independent directors enhance target shareholder wealth during tender offers? Journal of Financial Economics, 43(2), 195-218.

DeAngelo, H., \& DeAngelo, L. (1985). Managerial ownership of voting rights: A study of public corporations with dual classes of common stock. Journal of Financial Economics, 14(1), 33-69.

De Cesari, A., Gonenc, H., \& Ozkan, N. (2016). The effects of corporate acquisitions on CEO compensation and CEO turnover of family firms. Journal of Corporate Finance, 38, 294-317.

Díaz-Díaz, N. L., García-Teruel, P. J., \& Martínez-Solano, P. (2016). Debt maturity structure in private firms: Does the family control matter? Journal of Corporate Finance, 37, 393-411.

Dinh, T. Q., \& Calabrò, A. (2019). Asian family firms through corporate governance and institutions: a systematic review of the literature and agenda for future research. International Journal of Management Reviews, 21(1), 50-75.

Faccio, M. \& Lang, L. H. P. (2002). The ultimate ownership of Western European corporations. Journal of Financial Economics, 65(3), 365-395.

Fama, E. F., \& Jensen, M. C. (1983). Separation of ownership and control. Journal of Law and Economics, 26(2), 301-325.

Fooladi, M., Abdul-Shukor, Z. A., Saleh, N. M., \& Jaffar, R. (2014). The effect of corporate governance 
and divergence between cash flow and control rights on firm performance: Evidence from Malaysia. International Journal of Disclosure and Governance, 11(4), 326-340.

Frank, H., Kessler, A., Rusch, T., Suess-Reyes, J., \& Weismeier-Sammer, D. (2017). Capturing the familiness of family businesses: Development of the family influence familiness scale (FIFS). Entrepreneurship Theory and Practice, 41(5), 709-742.

Germain, L., Galy, N., \& Lee, W. (2014). Corporate governance reform in Malaysia: Board size, independence and monitoring. Journal of Economics and Business, 75, 126-162.

Ghosh, A. A., \& Tang, C. Y. (2015). Assessing financial reporting quality of family firms: The auditors $\bigotimes$ perspective. Journal of Accounting and Economics, 60(1), 95-116.

Guest, P. M. (2008) The determinants of board size and composition: Evidence from the UK. Journal of Corporate Finance, 14(1), 51-72.

Guest, P. M. (2009). The impact of board size on firm performance: evidence from the UK. European Journal of Finance, 15(4), 385-404.

González, M., Guzmán, A., Pombo, C., \& Trujillo, M. A. (2015). The role of family involvement on CEO turnover: Evidence from Colombian family firms. Corporate Governance: An International Review, 23(3), 266-284.

Halim, E. H., Mustika, G., Sari, R. N., Anugerah, R., \& Mohd-Sanusi, Z. (2017). Corporate governance practices and financial performance: The mediating effect of risk management committee at manufacturing firms. Journal of International Studies, 10(4), 272-289.

Haniffa, R. \& Cooke, T. E. (2002). Culture, corporate governance and disclosure in Malaysian corporations. Abacus A Journal of Accounting, Finance and Business Studies, 38(3), 317-349.

Haniffa, R. \& Hudaib, M. (2006). Corporate governance structure and performance of Malaysia listed companies. Journal of Business Finance and Accounting, 33(7-8), 1034-1062.

Hashim, H. A., \& Amrah, M. (2016). Corporate governance mechanisms and cost of debt: Evidence of family and non-family firms in Oman. Managerial Auditing Journal, 31(3), 314-336.
Hashim, H. A., \& Devi, S. (2008). Board characteristics, ownership structure and earnings quality: Malaysian evidence. Research in Accounting in Emerging Economies, 8(97), 97-123.

Hermalin, B. E. \& Weisbach, M. S. (1988). The determinants of board composition. Rand Journal of Economics, 19(4), 589-606.

Hooy, G. K., Hooy, C. W., \& Chee, H. K. (2019). Ultimate Ownership, Control Mechanism, and Firm Performance: Evidence from Malaysian Firms. Emerging Markets Finance and Trade. https://doi. org/10.1080/1540496X.2019.1584101

Hsiao, C. (2014). Analysis of Panel Data. Cambridge: Cambridge University Press.

Huang, M., Li, P., Meschke, F., \& Guthrie, J. P. (2015). Family firms, employee satisfaction, and corporate performance. Journal of Corporate Finance, 34, 108-127.

Hussain, H. I., Abidin, I. S. Z., Ali., A. \& Kamarudin, F. (2018) Debt Maturity and Family Related Directors: Evidence from a Developing Market. Polish Journal of Management Studies, 18(2), 118 - 134.

Hwang, S., \& Kim, W. (2016). When heirs become major shareholders: Evidence on pyramiding financed by related-party sales. Journal of Corporate Finance, 41, 23-42.

Ibrahim, H., \& Samad, F. A. (2011). Corporate governance mechanisms and performance of publiclisted family-ownership in Malaysia. International Journal of Economics and Finance, 3(1), 105-115.

Ismail, K. N. I. K., \& Manaf, K. B. A. (2016). Market reactions to the appointment of women to the boards of Malaysian firms. Journal of Multinational Financial Management, 36, 75-88.

Jensen, M. C. \& Meckling, W. H. (1976). Theory of the firm: Managerial behavior, agency costs and ownership structure. Journal of Financial Economics, 3(4), 305-306.

Johnson, S. \& Mitton, T. (2003). Cronyism and capital controls: Evidence from Malaysia. Journal of Financial and Economics, 67(2), 351-382.

Jong, L., \& Ho, P. L. (2018). Inside the family firms: The impact of family and institutional ownership on executive remuneration. Cogent Economics \& Finance, 6(1). https://doi.org/10.1080/23322039.2 018.1432095 
Kang, E. \& Zardkoohi, A. (2005). Board leadership structure and firm performance. Corporate Governance: An International Review, 13(6), 785-799.

Kothari, S. P., Laguerre, T. E. \& Leone, A. J. (2002). Capitalization versus expensing: Evidence on the uncertainty of future earnings from capital expenditure versus R\&D outlays. Review of Accounting Studies, 7(4), 355-382.

Kotlar, J., Signori, A., De Massis, A., \& Vismara, S. (2018). Financial wealth, socioemotional wealth, and IPO underpricing in family firms: A twostage gamble model. Academy of Management Journal, 61(3), 1073-1099.

Lane, S., Astrachan, J., Keyt, A. \& McMillan, K. (2006). Guidelines for family business boards of directors. Family Business Review, 19(2), 147-167.

La Porta, R., Lopez-De-Silanes, F. \& Shleifer, A. (1999). Corporate ownership around the world. Journal of Finance, 54(2), 471-517.

Liew, C. Y., Alfan, E., \& Devi, S. (2017). Family firms, expropriation and firm value: Evidence of the role of independent directors' tenure in Malaysia. International Journal of Organizational Leadership, 6(1), 42-64.

Lin, S. H. \& Hu, S. Y. (2007). A family member or professional management? The choice of a CEO and its impact on performance. Corporate Governance: An International Review, 15(6), 1348-1362.

López-Delgado, P., \& Diéguez-Soto, J. (2015). Lone founders, types of private family businesses and firm performance. Journal of Family Business Strategy, 6(2), 73-85.

Low, D. C. M., Roberts, H., \& Whiting, R. H. (2015). Board gender diversity and firm performance: Empirical evidence from Hong Kong, South Korea, Malaysia and Singapore. Pacific-Basin Finance Journal, 35, 381-401.

Neckebrouck, J., Schulze, W., \& Zellweger, T. (2018). Are family firms good employers? Academy of Management Journal, 61(2), 553-585.

Mak, Y. T., \& Li, Y. (2001). Determinants of corporate ownership and board structure: Evidence from Singapore. Journal of Corporate Finance, 7(3), 235-256.

Martínez-Ferrero, J., Rodríguez-Ariza, L., \& GarcíaSánchez, I. M. (2016). Corporate social responsibility as an entrenchment strategy, with a focus on the implications of family ownership. Journal of Cleaner Production, 135, 760-770.

Miller, D., Breton-Miller, I. L., Lester, R. H., \& Cannella, A. A. (2007). Are family firms really superior performers? Journal of Corporate Finance, 13(5), 829-858.

Mullins, W., \& Schoar, A. (2016). How do CEOs see their roles? Management philosophies and styles in family and non-family firms. Journal of Financial Economics, 119(1), 24-43.

Mulyani, E., Singh, H., \& Mishra, S. (2016). Dividends, leverage, and family ownership in the emerging Indonesian market. Journal of International Financial Markets, Institutions and Money, 43, 1629.

Nekhili, M., Chakroun, H., \& Chtioui, T. (2018). Women's leadership and firm performance: Family versus nonfamily firms. Journal of Business Ethics, 153(2), 291-316.

Ow-Yong, K., \& Guan, C. K. (2000). Corporate governance codes: A comparison between Malaysia and the UK. Corporate Governance: An International Review, 8(2), 125-132.

Petersen, M. A. (2009). Estimating standard errors in finance panel data sets: Comparing approaches. The Review of Financial Studies, 22(1), 435-480.

Pindado, J., Requejo, I., \& de La Torre, C. (2015). Does family control shape corporate capital structure? An empirical analysis of Eurozone firms. Journal of Business Finance \& Accounting, 42(7-8), 965-1006.

Rajan, R. G., \& Zingales, L. (1998). Which capitalism? Lessons from the East Asian crisis. Journal of Applied Corporate Finance, 11(3), 40-48.

Roodman, D. (2009). How to do xtabond2: An introduction to difference and system GMM in Stata. The Stata Journal, 9(1), 86-136.

Schmidt, S. L., \& Brauer, M. (2006). Strategic governance: How to assess board effectiveness in guiding strategy execution. Corporate Governance: An International Review, 14(1), 13-22.

Selcuk, E. A., \& Sener, P. (2018). Corporate Governance and Tunneling: Empirical Evidence from Turkey. Economics Bulletin, 38(1), 349-361

Sharif, S. P., Kyid, Y. K., \& Wei, K. K. (2015). The Acquisition of Valuable Resources by Family-Controlled Companies in Malaysia Through Political 
Connections of Their Independent Directors. Journal of Developing Areas, 49(5), 309-319.

Shim, I. (2006). Corporate credit guarantees in Asia. BIS Quarterly Review, 85-89. Retrieved from https://www.bis.org/publ/qtrpdf/r_qt0612i.pdf

Singam, K. (2003) Corporate governance in Malaysia. Bond Law Review, 15(1), 1-33.

Suto, M. (2003). Capital structure and investment behaviour of Malaysian firms in the 1990s: A study of corporate governance before the crisis. Corporate Governance: An International Review, 11(1), 25-39.

Tam, O. K. \& Tan, M. G.-S. (2007). Ownership, governance and firm performance in Malaysia. Corporate Governance: An International Review, 15(2), 208-222.

Thompson, S. B. (2011). Simple formulas for standard errors that cluster by both firm and time. Journal of Financial Economics, 99(1), 1-10.

van Essen, M., Carney, M., Gedajlovic, E. R., \& Heugens, P. P. M. A. R. (2015). How does family control influence firm strategy and performance? A meta-analysis of US publicly listed firms. Corporate Governance: An International Review, 23(1), 3-24.

Villalonga, B., Trujillo, M. A., Guzmán, A., \& Cáceres, N. (2018). What are boards for? Evidence from closely held firms in Colombia. Financial Management. https://doi.org/10.1111/fima.12224

Wagner, D., Block, J. H., Miller, D., Schwens, C., \& Xi, G. (2015). A meta-analysis of the financial performance of family firms: Another attempt. Journal of Family Business Strategy, 6(1), 3-13.

Wan Mohammad, W. M., Wasiuzzaman, S., \& Nik Salleh, N. M. Z. (2016). Board and audit committee effectiveness, ethnic diversification and earnings management: a study of the Malaysian manufacturing sector. Corporate Governance: The International Journal of Business in Society, 16(4), 726-746.

Wang, K., \& Shailer, G. (2015). Ownership concentration and firm performance in emerging markets: a meta-analysis. Journal of Economic Surveys, 29(2), 199-229.

Weisbach, M. S. (1988). Outside directors and CEO turnover. Journal of Financial Economics, 20, 431-460.
White, H. (1980). A heteroskedasticity-consistent covariance matrix estimator and a direct test for heteroskedasticity. Econometrica, 48(4), 817-838.

Windmeijer, F. (2005). A finite sample correction for the variance of linear efficient two-step GMM estimators. Journal of Econometrics, 126(1), 25-51.

Wu, C. Y. H., \& Hsu, H. H. (2018). Founders and board structure: Evidence from UK IPO firms. International Review of Financial Analysis, 56, 19-31.

Xu, N., Yuan, Q., Jiang, X., \& Chan, K. C. (2015). Founder's political connections, second generation involvement, and family firm performance: Evidence from China. Journal of Corporate Finance, 33, 243-259.

Yatim, P., Iskandar, T. M., \& Nga, E. (2016). Board attributes and foreign shareholdings in Malaysian listed firms. Journal of Management \& Governance, 20(1), 147-178.

Yatim, P., Kent, P. \& Clarkson, P. (2006). Governance structures, ethnicity, and audit fees of Malaysian listed firms. Managerial Auditing Journal, 21(7), 757-782.

Yermack, D. (1996). Higher market valuation of companies with a small board of directors. Journal of Financial Economics, 40(2), 185-211.

Yoong, L. C., Alfan, E., \& Devi, S. S. (2015). Family firms, expropriation and firm value: Evidence from related party transactions in Malaysia. Journal of Developing Areas, 49(5), 139-152.

Zabri, S. M., Ahmad, K., \& Wah, K. K. (2016). Corporate Governance Practices and Firm Performance: Evidence from Top 100 Public Listed Companies in Malaysia. Procedia Economics and Finance, 35, 287-296. 
